\title{
ЕКОЛОГІЧНІ ПРОБЛЕМИ СТАЛОГО РОЗВИТКУ ТА ЗБЕРЕЖЕННЯ НАВКОЛИШНЬОГО СЕРЕДОВИЩА В КОНТЕКСТІ НАВЧАННЯ СТУДЕНТІВ
}

\author{
Малишев В. В., Шахнін Д. Б.
}

\section{ВСТУП}

Серйозним спонукальним та об'єднувальним моментом у боротьбі за збереження довкілля $\epsilon$ так звані «зелені» рухи та «зелені» технології ${ }^{1,2}$. Початок «зеленому» руху було покладено ще в 60-і роки XX століття, коли громадськість Північної Америки та Західної Європи, яка виступає за збереження навколишнього середовища, домоглася посилення природоохоронного законодавства й контролю за використанням токсичних хімікатів у різних галузях економіки та соціальної сфери. Окрім штрафних санкцій i заборони застосування ряду особливо небезпечних хімікатів, посилилась увага до пошуку менш токсичних заміщувальних хімічних речовин, альтернативних технологій енерго- та ресурсозбереження. Більше того, законодавчо був уведений токсикологічний контроль отриманих і застосовуваних хімічних речовин та матеріалів.

Визначення «зеленої» хімії, прийняте ІЮПАК, таке: «Зелена хімія - відкриття, розробка й використання хімічних продуктів та процесів, які зменшують або виключають використання й утворення шкідливих речовин». Визначення прямо вказує на необхідність урахування можливих негативних явищ ще на стадії створення нових сполук, про що раніше дослідники часто не замислювалися. Поль Анастас та Джон Корнер сформулювали 12 принципів

${ }^{1}$ Тарасова Н.П., Нефедов О.М., Лунин В.В. Химические проблемы устойчивого развития и сохранения окружающей среды. Успехи химии. 2010. Т. 79, № 6. C. 491-492. URL : https://doi.org/10.1070/RC2010v079n06ABEH004149.

2 Лукашенко Т.Ф., Малишев В.В. Екологічна хімія. Навчальний посібник до спецкурсу «Екологічна хімія» для студентів напрямів підготовки «Хімічна технологія та інженерія», «Екологія», «Біологія». Київ : Університет «Україна», 2012. 269 c. 
«зеленої» хімії, які стали нині класичними³ розкривають практичні аспекти визначення ІЮПАК, $є$ такими:

- запобігання утворенню відходів;

- раціональне (ефективне) використання вихідних реагентів;

- зниження загроз процесів і продуктів синтезу;

- конструювання «зелених» матеріалів;

- виключення використання небезпечних допоміжних реагентів;

- енергозбереження в хімічних процесах;

- використання відновлюваної сировини;

- зменшення числа проміжних стадій технологічних процесів;

- використання каталізаторів для прискорення хімічних процесів;

- біорозкладання для отримання сполук, безпечних для наволишнього середовища;

- забезпечення аналітичного контролю в реальному часі;

- попередження можливості техногенних аварій.

\section{1. Предмет дослідження екологічної науки, екологічна ситуація сьогодення та екологічна освіта}

Термін «екологія» став останнім часом «усепроникним» i «всеосяжним». Будь-яка наука сьогодні без видимих зусиль установлює свою предметну галузь екологічних досліджень. Такий феноменальний злет екологічного напряму небезпідставний і потребує уточнень.

Термін екологія вперше вжив у 1866 році німецький учений Е. Геккель. Він походить від грецьких слів oikos, що означає дім, помешкання, місце перебування та $\operatorname{logos}$ - наука. Так Геккель назвав науку, що вивчає організацію та функціонування надорганізмових систем різних рівнів: видів, популяцій, біоценозів та біосфери. Спочатку цей термін використовувався тоді, коли йшлося про вивчення взаємозв'язків між рослинними та живими спільнотами, що входять до складу стійких та організованих систем, які склалися у процесі еволюції органічного світу з навколишнім середовищем.

Насправді, предметом дослідження екології є детальне вивчення за допомогою кількісних методів основ структури та функціонування природних та створених людиною систем. Жива

${ }^{3}$ Anastas P., Eghbali N. Green Chemistry: Principles and Practice Chem. Soc. Rev. 2010. V. 39. P. 301-312. URL : https://doi.org/10.1039/B918763B. 
природа, що оточує нас, - це не безладне, випадкове поєднання живих істот. Вона $є$ стійкою організованою системою органічного світу, що склалася в процесі його еволюції. Центральне місце в екології посідає проблема динаміки й чисельності популяції і механізмів іiі регулювання. Тут виявляється значимість участі популяційних (конкуренція за їжу) та біоценотичних (хижаків, паразитів, збудників захворювання) механізмів.

Серед основних завдань екології можна виділити такі:

-дослідження особливостей організації життя, в тому числі у зв'язку з антропогенним, що є результатом людської діяльності, впливом на природні системи;

-створення наукової основи раціональної експлуатації біологічних ресурсів;

- прогнозування змін природи під впливом діяльності людини;

-збереження середовища існування людини.

Збалансованість взаємовідносин людини з видами, популяціями та спільнотами може бути досягнута за рахунок комплексних зусиль iз боку людини шляхом екологічної регламентації господарської діяльності, цілеспрямованого, екологічно виправданого впливу на види, популяції та екосистеми, шляхом екологічного виховання підростаючих поколінь.

Завдяки цьому може бути розв'язано багато проблем господарської діяльності суспільства:

1) інтенсифікація виробництв ряду галузей;

2) збереження та заощадження сировини;

3) охорона історичних та архітектурних пам'яток;

4) збільшення часу експлуатації промислових та житлових комплексів;

5) збільшення тривалості життя та зниження захворюваності людей в умовах урбанізованого середовища;

6) вдосконалення механізмів взаємодії суспільства та природи.

Характерною рисою екології $\epsilon$ те, що вона не належить до числа наукових дисциплін із простою лінійною структурою, оскільки вона $€$ міждисциплінарною. У процесі свого розвитку та освоєння людиною нових дисциплін екологічні знання повинні неперервно накопичуватися. Екологія є спільною базою співпраці фахівців усіх напрямків: натуралістів та інженерів, експериментаторів та вченихтеоретиків, біологів, математиків, економістів, медиків, метеорологів, для яких екологічні знання є просто необхідними. 
Набуття кожною людиною екологічних знань буде сприяти дбайливому ставленню до природи, збереженню іiі та меншій кількості ударів з іiі боку у відповідь за бездумне ставлення до неї. Усе більше людей бере участь у діяльності 3 охорони навколишнього середовища, а екологія стає все важливішою для життя людини і її існування на планеті. Думати глобально, а діяти локально - ось актуальний екологічний девіз сьогодення ${ }^{4}$.

Сучасний стан навколишнього природного середовища переконливо свідчить, що факти, які детермінують загострення екологічної ситуації, об'єктивно діють у будь-якому індустріальному суспільстві незалежно від соціально-економічного ладу, але значно корелюючись (посилюючись або послаблюючись) чинниками техніко-технологічного, а головне - економічного та соціокультурного порядку, рівнем розвитку демократії у сфері політики та господарства, можливостями впливу громадян на центри й процеси прийняття рішень тощо.

Наш час - це період тотальної екологічної освіти, коли основи екологічних знань викладають усім, починаючи 3 дитячого віку в школах та інститутах, на різних семінарах і курсах, по радіо й телебаченню - та закінчуючи підвищенням рівня екологічної освіти керівників усіх рангів у всіх країнах, на всіх континентах. У більшості країн світу екологія стала обов'язковою дисципліною в усіх школах і вищих закладах освіти, в багатьох вищих навчальних закладах створено кафедри або факультети екологічного профілю, проведено сотні екологічних національних і міжнародних семінарів, конференцій, з'їздів. Велику еколого-просвітницьку роботу проводять у всьому світі організації «зелених», товариства $з$ охорони природи, серед них такі відомі, як «Грінпіс», «Легамбіенте» тощо. Ці важливі для цивілізації процеси екологізації свідомості населення, формування нового екологічного світогляду, нової - екологічної культури цілком характерні і для України.

За останні 5 років у нашій державі також розроблено програми й концепції розвитку екологічної освіти й виховання, видано посібники й підручники 3 екології, створено десятки кафедр i факультетів екологічного профілю в інститутах та університетах, започаткувалося багато журналів загальноекономічного, еколого-

${ }^{4}$ Лукашенко Т.Ф., Малышев В.В. Формирование экологической компетентности - важная составляющая экологического образования. Экологическая химия. 2012. Т. 21. № 4. С. 252-256. 
економічного, еколого-географічного змісту («Ойкумена», «Світ у долонях», «Пролісок», «Паросток», «Рідна природа» тощо).

Ще в 1975 р. учасники Міжнародного семінару з екологічної освіти (Белград, Югославія) запропонували глобальну схему екологічної освіти. Відповідно до цієї схеми головною метою екологічної освіти має бути формування в населення планети усвідомлення того, що довкіллям необхідно опікуватися й що для цього треба мати відповідні знання, досвід, уміння, мотивації та зобов'язання як для індивідуальної, так і для колективної роботи задля порятунку біосфери та запобігання майбутнім екологічним катастрофам.

Сьогодні активно розвиваються як формальна екологічна освіта (у школах, вищих навчальних закладах, інститутах підвищення кваліфікації), так і неформальна (за допомогою засобів масової інформації, кіно, музеїв, виставок, заходів природоохоронних товариств тощо).

Концепція освіти в Україні повинна враховувати безпрецедентну інтегративність екології, іiі орієнтацію на вивчення сфери безпосередніх життєвих інтересів людини. Від формування цих знань залежить певний рівень ставлення людини до навколишнього середовища, тобто не лише знання і розуміння, але й виховання. Від цих знань залежить саме існування людства і всієї планети Земля.

Підвищення культури громадян України у спілкуванні із природою, екологічна підготовка кадрів в умовах складного перехідного періоду мають важливе державне значення, оскільки покликані допомогти у вирішенні життєво важливих соціальноекономічних, еколого-економічних і геополітичних проблем.

В останне десятиліття в системі екологічних наук з'явились нові наукові і навчальні дисципліни: екологія міст, екологія особистості, екологія дитини тощо. Заявила про себе і визначена як одна з важливих складових частин системи екологічних дисциплін соціальна екологія. 3 огляду на це $\epsilon$ необхідність розширити і поновому сформулювати предмет дослідження та вивчення загальної і соціальної екології.

Аналіз тенденцій глобальних, регіональних і локальних змін у природних екосистемах та біосфері загалом свідчить про нагальну потребу формування у студентів економічних спеціальностей із метою набуття грунтовних екологічних знань та культури спілкування із природою необхідних навичок раціонального 
природокористування, екологізації практично всіх навчальних дисциплін.

Тому навчальний курс «Основи екології» займає сьогодні належне місце серед найголовніших та фундаментальних дисциплін. Навчальна програма з курсу, що рекомендована $\mathrm{MOH}$, розроблена з урахуванням сучасних вимог до рівня екологічних знань, наявності базових екологічних знань, отриманих у школі, світового й вітчизняного досвіду.

Обсяг екологічного матеріалу, отриманого студентами внаслідок успішного засвоєння курсу «Основи екології», повинен забезпечити розуміння екологічної аксіоматики, сформувати в кожного з них особисте ставлення до екологічних проблем світу, рідного краю, а також галузі майбутньої діяльності, що особливо важливо в межах нашого дослідження, допомогти враховувати екологічні вимоги і стандарти під час вирішення інженерних та інших завдань, забезпечити запас фундаментальних знань і концептуальних основ сучасної екології, достатній для подальшого поглиблення й удосконалення екологічної освіти, спрямованої на екологічно безпечну життєдіяльність.

Курс «Основи екології» включає інформацію про фундаментальні теоретичні, глобальні екологічні i ресурсно-галузеві екологічні проблеми, стратегію, тактику і методи їх розв'язання локального, національного і глобального рівнів. Зміст курсу «Основи екології» побудовано на основі сучасних уявлень про сутність, структуру, цілі й завдання екології, іiі значення в житті суспільства, місце і зв'язок з іншими науками. Система отриманих на цій основі знань має забезпечити формування чітких $\mathrm{i}$ обгрунтованих уявлень про взаємодію і взаємозв'язок усіх компонентів у природничій, соціальній i технологічній сферах, про стратегію i тактику збереження й стабільного розвитку життя на Землі.

На нашу думку, у зв'язку 3 викладеним очевидною $\epsilon$ необхідність змін у структурі екологічної освіти, оновлення іiі змісту, реалізованого в системі традиційних i нових наукових понять, дидактично і методично пов'язаних із різними освітніми і освітньо-професійними рівнями; потрібне оновлення технологій навчання екології, спрямованих на реалізацію програм неперервної освіти, навчальних планів дисциплін різних рівнів засвоєння. 


\section{2. Структура та зміст екологічної освіти у вищих навчальних закладах України. Її методологічна основа та принципи}

Останнім часом істотно посилився вплив людини на природу. За останні 40-50 років людство встигло пройти більшу частину шляху, який відділяє планету від екологічної катастрофи. Шкідливі виробничі і побутові відходи стали суттєво перекривати можливості біосфери щодо їх природної переробки й нейтралізації. Вони стали нагромаджуватися в атмосфері, воді, грунті й виявляти руйнівну дію на природні цикли, що складалися мільйони років. Дедалі більше посилюється нестача сировинних ресурсів, може настати загроза нестачі кисню й питної води.

Ураховуючи значимість екологічної освіти, слід визначити іiі природу й завдання. 3 огляду на те, що захист і поліпшення середовища потребують включення в цю діяльність широких мас населення різного віку, рівня освіти і різної професійної орієнтації, екологічна освіта повинна бути пристосована до всіх цих категорій населення, розвивати в них розуміння необхідності підтримувати екологічну рівновагу в середовищі, що оточує людину, і запобігати небезпеці, яка може загрожувати людині в разі їі порушення.

Існують різноманітні трактування екологічної освіти. Наприклад, думка, що слід дати знання й розвинути здатність оцінювати становище та бачити комплексні проблеми стосовно середовища. Також $є$ думка, що екологічна освіта повинна вносити вклад у формування конструктивного підходу до середовища - як у філософському, так і в прагматичному плані. $€$ розуміння того, що екологічна освіта повинна займатися ставленням людини до іiі природного та штучного середовища, має охоплювати проблеми населення, забруднення, використання ресурсів, збереження природи. Можна сказати, що в різних визначеннях присутня одна $\mathrm{i}$ та сама думка: екологічна освіта - це освіта із глобальних умов існування людства і стратегії збереження цих умов при постійному поліпшенні якості життя. Метою екологічної освіти $є$ розвиток уявлень про основні характеристики середовища, що оточує людину, відношення в ній і до неї, на основі чого людина прагне до збереження й поліпшення середовища.

По суті, екологічна освіта в рамках навчання має зробити внесок у новий підхід у ставленні людини до свого середовища - як єдності природного i штучного, пов'язуючи знання природничих і суспільних наук про середовище як єдиний і необхідний життєвий простір людини, який можна зберегти і при постійному розвитку 
науки і техніки. Однак екологічна освіта може робити внесок не лише у стратегію існування, а й у поліпшення якості життя в конкретних середовищах.

Методологічною основою екологічної освіти слід вважати такі положення:

1. Світ матеріальний являє собою складну систему зв'язків і взаємовідносин, тобто зміни його елементів взаємозумовлені.

2. Захист природи являє собою застосування закону відносин і взаємних дій, що існують у матеріальному світі.

3. Людина і суспільство - наслідок еволюції живої природи (суспільство і природа становлять неподільне суперечливе ціле).

4. Зміни в біосфері, шкідливі для людини і суспільства, зумовлені відсутністю або недостатністю заходів у регулюванні взаємодії суспільства і природи.

5. Існує вплив природи на темпи розвитку суспільства, але відсутній вплив природи на характер суспільних відносин 5 .

Виходячи із цього, екологічна освіта намагається відповісти на запитання:

- які наслідки зрослої інтенсифікації в обміні матерією і енергією між природою і суспільством;

- які найважливіші зміни в системі взаємовідносин у біосфері;

- які наслідки має введення до біосфери великої кількості нових речовин і елементів;

- які суспільні детермінанти ставлення суспільства до природи i чи повинен захист природи відбуватися через гальмування технічного прогресу;

- в чому суть відповідальності людини за стан навколишнього середовища?

Екологічна освіта має за мету формування екологічної свідомості, вона робить внесок у розвиток уявлення про те, що порушення екологічної рівноваги необов'язково супроводжує діяльнісне ставлення до природи, але виникає в рамках певних соціально-економічних відносин. Екологічна освіта повинна робити внесок у розуміння того, що збереження середовища людини стає важливою категорією в системі цінностей суспільства і воно

${ }^{5}$ Проблеми освіти. Наук.-метод. зб. Київ : ІЗМН, 1998. Вип. 14. 232 с. 256 
повинно стати предметом етичного ставлення людей до їх природного і суспільного середовища.

Такі цілі екологічної освіти зумовлюють іï присутність не лише на всіх сходинках системи освіти, а й у додатковій, неперервній освіті. У галузі вищої освіти не існує концептуально і змістовно побудованої системи екологічної освіти й виховання, яка відповідала б вимогам суспільства, за винятком окремих предметів у навчальних планах ВН3, в яких має бути проблематика захисту середовища. У навчальних програмах з інших предметів екологічні проблеми якщо і присутні, то викладені фрагментарно і в невеликому обсязі.

Курс «Основи екології» $\epsilon$ складовою частиною навчальних планів усіх напрямів підготовки спеціалістів із вищою освітою і входить до блоку дисциплін природничо-наукової підготовки. Курс включає інформацію про фундаментальні теоретичні, глобальні екологічні i ресурсно-галузеві екологічні проблеми, стратегію, тактику і методи їх вирішення локального, національного і глобального рівнів.

Із другої половини 70-х років екологічна освіта в Україні стає обов'язковою. Спочатку існував спорадичний факультатив, присвячений охороні природи. Після Тбіліської конференції під егідою ООН (1988) викладання набуває певної системності. За розмовами про важливість екологічної освіти лишилося непоміченим справді основне і принципове: змінилася парадигма екологічної освіти. Спочатку метою було формування психологічної настанови на раціональне природокористування, охорону природи взагалі. Тепер ставиться завдання формувати екологічну свідомість, культуру, мораль, етику. Тобто прагматику заступили світоглядні цінності.

Сьогодні існують різні тенденції екологічної освіти стосовно пріоритету формування тих або інших підструктур екологічної свідомості. Відповідно до стратегічних орієнтацій в екологічній освіті існують три основні підходи до проблеми змісту екологічної освіти ${ }^{6}$ Перший підхід пов'язаний із формуванням екологічних уявлень. Для студентів вищої школи сьогодні практично не існує концептуальної та змістовно побудованої системи екологічної освіти, за винятком хіба що окремих предметів. Другий підхід формування ставлення до природи. Обираються така екологічна

${ }^{6}$ Корсак К.В., Плахотнік О.В. Основи екології : навч. посібн. 3-е вид., перероб. і доп. Київ : МАУП, 2002. 296 с. 
інформація і такі види діяльності, які передбачають взаємини суб'єкта із природою. Третій підхід пов'язаний із формуванням технологій взаємодії із природою.

Екологічна освіта із середини 80 -х років невпинно входить в освітню практику, однак без жодного позитивного ефекту. Основна причина в тому, що екологічна освіта $80-\mathrm{x}$ років орієнтована на гербартську педагогіку, що діє за принципом виховального навчання. Вихованці накопичують екологічну інформацію, екологічні знання, але екологічна культура при цьому не формується. Як наслідок маємо екологічно обізнану й екологічно невиховану особистість, яка, володіючи екологічними знаннями, проявляє актив екологічного вандалізму. Тому невідкладним є розроблення стратегії екологічного виховання, оскільки вважається, що здійснюється воно автоматично - разом 3 екологічним навчанням. Ясна річ, процеси навчання й виховання тісно пов'язані між собою, хоча екологічне навчання - це власне складова частина природничо-наукової освіти, а екологічне виховання має ціннісний аспект, адже передусім ідеться про формування психоемоційної сфери студента.

Для правильної організації екологічної освіти й виховання у вищих навчальних закладах, підвищення іiі ефективності слід керуватися такими принципами:

- першочергове завдання екологічної освіти - формування наукових уявлень про біосферу як унікальну оболонку Землі, де існує життя, - екологічна освіта повинна пов'язувати засвоєння наукових уявлень про біосферу 3 розвитком діалектично суперечливої єдності «біосфера - людство»;

- екологічні проблеми тісно пов'язані 3 демографічними, енергетичними, продовольчими й сировинними проблемами. Екологічна освіта перебуває на стику наук про природу i про людину. Тому під час розроблення питань про зміст та форми роботи, методи і методики екологічного виховання виходять із того, що воно є одним із найважливіших напрямів забезпечення синтезу природних i соціальних наук у процесі навчання, виховання і освіти;

- екологічна освіта має формувати наукові уявлення про соціальне коріння глобальних екологічних проблем. Проблеми взаємозв'язку природи i суспільства тісно переплітаються 3 широким колом етичних і естетичних питань; 
- навколишнє середовище, природне і створене людством, має розглядатись як єдине ціле, підходити до його оцінки і характеристик слід 3 екологічних, економічних, соціальних, законодавчих, культурних і естетичних позицій;

- цілі, які стосуються розуміння та вирішення проблем, пов'язаних iз навколишнім середовищем, мають бути чітко виокремлені з-поміж цілей освіти на всіх рівнях і всіх секторах;

- має бути узгоджений той вклад, який різні галузі науки повинні внести в розуміння навколишнього середовища $\mathrm{i}$ в розв'язання його проблем, роблячи при цьому особливий акцент на розвитку відносин, які дозволяють приймати спосіб життя і моделі розвитку, що не справляють негативного впливу на якість навколишнього середовища;

- екологічна освіта та виховання повинні бути безперервними і являти собою підсистему в системі вищої освіти;

- необхідно дотримуватися міждисциплінарного підходу, тобто розглядати екологічні питання не як окремі дисципліни, a, насамперед, як принцип, за якого всі дисципліни навчального плану пронизані ідеями збереження довкілля. Це дає змогу отримати цілісне уявлення про навколишнє середовище, озброїти майбутніх спеціалістів засобами ефективного впливу на нього;

- внаслідок міжгалузевого характеру проблем із навколишнього середовища підготовка кадрів повинна здійснюватись переважно на рівні спеціалізації;

- екологічна освіта і виховання повинні орієнтуватись на активну взаємодію людини із природою, побудовану на науковій основі, на оцінюванні людини як частини природи;

- екологічні знання, доповнені ціннісними орієнтаціями, повинні стати основою екологічної культури й екологічного мислення.

Розвиток екологічної освіти привів до виділення іiї специфічних особливостей:

1) усвідомлення складності охорони навколишнього середовища та її вивчення з позиції системного аналізу;

2) усвідомлення глобального характеру екологічних проблем;

3) міждисциплінарний підхід;

4) урахування та пізнання зв'язку екологічних проблем 3 економічними, культурними та соціальними проблемами;

5) різноманітність джерел знання та методів навчання.

Екологічну освіту необхідно звести не стільки до передавання знань 3 окремих тем, скільки до формування екологічного 
світогляду. Економіст, який мислить, повинен розуміти причиннонаслідкові зв'язки у природних явищах, уміти простежити, в якому взаємозв'язку вони з іншими явищами ширшої системи. Екологічні цілі повинні стати базисними цілями економіки.

За останні 15-20 років питання екологічної освіти та виховання зі сфери дискусій про правомірність екологічної освіти змістилося у площину іiі практичної реалізації. Ця обставина значно впливає на педагогіку й сучасну систему освіти. Зокрема, робиться спроба педагогічного осмислення ключових для сучасної екології категорій - свідомості, моралі, етики, культури та інших понять, правомірність існування яких ще недавно рішуче заперечувалася, як таких, що нібито стоять над мораллю суспільства, а людину ставлять у позицію сліпого поклоніння перед природою, тоді як справжнім завданням екологічної освіти, на думку ідеологів від освіти, слід вважати «наукове обгрунтування перебудови біосфери в інтересах людини».

Екологічна освіта розвиває комунікативні можливості людини через сучасний інформаційно-зв'язковий мінімум кожної людини. Екологічна освіта у вищому навчальному закладі підпорядковується основній меті - дати молоді світоглядні цінності. Тому предмет екології має бути віднесеним до базових дисциплін гуманітарного циклу.

Аналізуючи державні навчальні програми з екології, ми виявили спрямованість на формування екологічної свідомості у студентів, на раціональне використання природних ресурсів, кількість і якість яких щорічно зменшується.

Добір змісту екологічної освіти i виховання у вищому навчальному закладі передбачає певний набір і зміст навчальних предметів, струнку іï систему, взаємозв'язок і послідовність введення, визначення знань, умінь і навичок, якими мусить володіти майбутній фахівець 3 економіки, а також систему поняттєвотермінологічного апарату.

У вищих навчальних закладах України здійснюється єдина (базова) екологічна освіта. Її основою є інтегрований курс «Основи екології», який включає найважливіші аспекти екологічної проблеми і враховує певні концептуальні положення.

- Природне середовище (біосфера) $є$ саморегулівною системою, яка перебуває у стані динамічної рівноваги і виявляє стійкість у досить широкому, але кінцевому діапазоні зовнішніх 
впливів. Воно накладає певні обмеження на темпи і масштаби соціально-економічного розвитку людства, які зумовлюються розмірами планети Земля, запасами іiі ресурсів, можливостями саморегуляції і підтримання рівноваги.

- Стан природного середовища на сучасному етапі розвитку людства $\epsilon$ наслідком взаємодії його біологічних і фізичних аспектів 3 аспектами соціально-економічного i культурного розвитку суспільства. Екологічні проблеми мають глобальний, регіональний, національний і місцевий характер. Аналіз усіх проблем повинен здійснюватися у відповідності з їх проявом, на основі врахування певних вимог екологічного, економічного й політичного характеру, виходячи з ресурсних можливостей природного середовища.

- Виснаження природних ресурсів планети, забруднення середовища й порушення природної рівноваги внаслідок стихійної діяльності людства неминуче призведе до загальнопланетарної екологічної кризи. Потрібно істотно змінити виробничу основу діяльності людства, виходячи 3 ресурсних можливостей планети Земля, необхідності технологічної модернізації виробництва, яке б максимально вписувалося в біологічні цикли природи.

Під час формування у студентів особистісного ставлення до екологічної дійсності важливо чітко окреслювати коло екологічних проблем усього людства, своєї країни і своєї місцевості. Лише за цих умов можна проводити справді ефективну роботу. Так, під час вивчення теми «Екологічні проблеми оболонок Землі», а саме питання «Екологічні проблеми водного середовища і його охорона», необхідно звернути увагу студентів на обмеженість водних ресурсів нашої країни. Для підкреслення важливого значення води в житті людини можна використати слова Антуана де Сент-Екзюпері: «Вода, ти не маєш ні смаку, ні запаху, тебе неможливо описати, тобою насолоджуюся, не знаючи, що ти таке. Не можна сказати, що ти необхідна для життя, ти - саме життя».

Дидактичними умовами формування екологічних знань у студентів економічних спеціальностей є такі:

Принцип науковості. Його сутність - усі факти, знання, положення i закони, що вивчаються, повинні бути науково правильні, так само, як і спосіб обгрунтування положень і законів та формування понять у процесі навчання ${ }^{7}$.

${ }^{7}$ Скрипко Т. Екологічний аспект освітньої діяльності українців найдавніших часів. Освіта і управління. 1998. № 2. С. 112-121. 
Принции систематичності й послідовності навчання передбачає системність у роботі студентів (систематичне відвідування занять, увага на лекціях, систематичне повторення навчального матеріалу).

Принцип доступності навчання. Реалізація цього принципу передбачає: врахування рівня розвитку; індивідуальних особливостей; дотримання правил: від простого - до складного, від відомого - до невідомого, від близького - до далекого.

Принции зв'язку навчання з життям. Реалізацію цього принципу забезпечують: використання на семінарах життєвого досвіду студентів; застосування набутих знань у практичній діяльності; розкриття практичної значимості знань; безпосередня участь студентів у громадському житті.

Метод екологічної ідентифікаиії полягає в педагогічній актуалізації особистої причетності людини до того чи іншого природного об'єкта, ситуацій, обставин, в яких він перебуває. Цей метод стимулює процес психологічного моделювання стану природних об'єктів, сприяє кращому розумінню цього стану, що поглиблює уявлення школярів про даний об’єкт. Крім того, цей механізм актуалізує відповідну поведінку щодо цього об'єкта.

Метод екологічної емпатії має на меті педагогічну актуалізацію співпереживання людини за стан природного об'єкта, а також співчуття йому. Це стимулює проекцію особистих станів на природні об'єкти через ототожнення з ними (співпереживання), а також переживання особистих емоцій та почуттів із приводу стану природних об'єктів (співчуття). Таким чином формується суб'єктифікація природних об'єктів.

Метод екологічної рефлексії полягає в педагогічній актуалізації самоаналізу людиною своїх дій та вчинків 3 точки зору їх екологічної доцільності. Цей метод стимулює усвідомлення того, який вигляд може мати поведінка людини, 3 точки зору тих природних об'єктів, яких вона стосується.

Ураховуючи досвід спеціалістів у галузі екологічного виховання, можна виділити чотири типи студентів за їх психологодидактичними особливостями.

1. Це ті, хто навчається через почуття. Вони чутливіші до людей та оточення. Тому вони краще навчаються через специфічний досвід, менше орієнтовані на авторитети, ніж інші, не шукають теоретичних підходів до вирішення проблеми, більшу допомогу отримують від дискусій та роботи в парах, тому в навчальних 
ситуаціях більш відкриті, швидко адаптуються до них та діють переважно інтуїтивно.

2. Ті, хто навчається, спостерігаючи та слухаючи. Учні та студенти цієї групи довіряють лише ретельному дослідженню у формуванні висновків, надають перевагу ситуаціям, які дозволяють їм бути об'єктивними спостерігачами. Вони спираються лише на особисті думки та відчуття під час формування поглядів на конкретну проблему, можуть бачити різні перспективи і часто шукають суть предмета. Тому вони більше розкриваються на лекціях та демонстраціях.

3. Ті, хто навчається через мислення. Ця група людей винаходить аналітичні, концептуальні підходи у вирішенні проблеми, надає перевагу винятково логічному мисленню та раціональній оцінці. Вони більш орієнтовані на речі та символи, краще навчаються в авторитарно спрямованих ситуаціях, які базуються на теоріях та синтетичному аналізі; часто спростовують «винахідливе» навчання i віддають перевагу систематичному плануванню та навчанню.

4. Ті, хто навчається через дію. Останню групу складають дійові особи, які довіряють винятково експериментам і краще навчаються, коли мають можливість узяти участь у проекті або дискусіях. Вони ігнорують лекції та інші пасивні форми навчання та виховання.

\section{ВИСНОВКИ}

«Зелені рухи» та «зелені технології» $\epsilon$ спонукальним та об'єднувальним моментом у боротьбі за збереження довкілля. Практичне застосування «зеленої хімії» грунтується на використанні 12 принципів: запобігання утворенню відходів; раціональне (ефективне) використання вихідних реагентів; зниження загроз процесів і продуктів синтезу; конструювання «зелених» матеріалів; виключення використання небезпечних допоміжних реагентів; енергозбереження в хімічних процесах; використання відновлюваної сировини; зменшення числа проміжних стадій технологічних процесів; використання каталізаторів для прискорення хімічних процесів; біорозкладання для отримання сполук, безпечних для навколишнього середовища; забезпечення аналітичного контролю в реальному часі; попередження можливості техногенних аварій.

Основними завданнями екології є: дослідження особливостей організації життя, в тому числі в зв'язку з антропогенним, що $\epsilon$ результатом людської діяльності, впливом на природні системи; 
створення наукової основи раціональної експлуатації біологічних ресурсів; прогнозування змін природи під впливом діяльності людини; збереження середовища існування людини.

Вирішення цих завдань допоможе розв'язанню таких проблем господарської діяльності суспільства: інтенсифікація виробництв ряду галузей; збереження та заощадження сировини; охорона історичних та архітектурних пам'яток; збільшення часу експлуатації промислових та житлових комплексів; збільшення тривалості життя та зниження захворюваності людей в умовах урбанізованого середовища; вдосконалення механізмів взаємодії суспільства та природи.

Запропонований навчальний курс «Основи екології» займе належне місце серед найголовніших фундаментальних дисциплін. Навчальна програма курсу розроблена $з$ урахуванням сучасних вимог до рівня екологічних знань, наявності базових екологічних знань, отриманих у школі, світового й вітчизняного досвіду. Зміст курсу «Основи екології» побудовано на основі сучасних уявлень про сутність, структуру, цілі й завдання екології, іï значення в житті суспільства, місце й зв'язок з іншими науками. Система отриманих на цій основі знань має забезпечити формування чітких i обгрунтованих уявлень про взаємодію i взаємозв'язок усіх компонентів у природничій, соціальній і технологічній сферах, про стратегію і тактику збереження й стабільного розвитку життя на Землі.

\section{АНОТАЦІЯ}

Досліджено екологічні проблеми сталого розвитку та збереження навколишнього середовища в контексті навчання студентів. Наведено перелік основоположних принципів „зеленої хімії”. Розглянуто основні завдання екології та проблеми господарської діяльності суспільства. Стан сучасної екологічної освіти співставлено з екологічною ситуацією сьогодення. Запропоновано курс «Основи екології», що включає теоретичні, стратегічні, тактичні проблеми. Наведено структурний зміст цього курсу. Запропоновано методологічну основу екологічної освіти у вищих навчальних закладах. Визначено предмет дослідження, основні завдання та міждисциплінарний характер екологічної науки. 


\section{ЛІТЕРАТУРА}

1. Тарасова Н.П., Нефедов О.М., Лунин В.В. Химические проблемы устойчивого развития и сохранения окружающей среды. Успехи химии. 2010. Т. 79. № 6. С. 491-492.

2. Лукашенко Т.Ф., Малишев В.В. Екологічна хімія. Навчальний посібник до спецкурсу «Екологічна хімія» для студентів напрямів підготовки «Хімічна технологія та інженерія», «Екологія», «Біологія». Київ : Університет «Україна», 2012. 269 с.

3. Anastas P., Eghbali N. Green Chemistry: Principles and Practice. Chem. Soc. Rev. 2010. V. 39. P. 301-312. URL : https://doi.org/10.1039/B918763B

4. Лукашенко Т.Ф., Малышев В.В. Формирование экологической компетентности - важная составляющая экологического образования. Экологическая химия. 2012. Т. 21. № 4. С. 252-256.

5. Проблеми освіти : наук.-метод. зб. Київ : ІЗМН, 1998. Вип. 14. $232 \mathrm{c}$.

6. Корсак К.В., Плахотнік О.В. Основи екології : навч. посібн. 3-е вид., перероб. і доп. Київ : МАУП, 2002. 296 с.

7. Скрипко Т. Екологічний аспект освітньої діяльності українців найдавніших часів. Освіта і управління. 1998. № 2. С. 112-121.

\section{Information about authors:} Malyshev V. V.,

Doctor of Technical Sciences, Professor, Director of Institute of Engineering \& Technology Open International University of Human Development "Ukraine" 23, Lvivska St., Kyiv, 03115, Ukraine

Shakhnin D. B., Ph.D., Associated Professor, Associated Professor of the Department of Modern Engineering and Nanotechnologies Open International University of Human Development "Ukraine" 23, Lvivska St., Kyiv, 03115, Ukraine 